\title{
The effect of periodontal bacteria infection on incidence and prognosis of cancer: a systematic review and meta-analysis
}

\author{
Li Xiao \\ North Sichuan Medical University \\ Qianyu Zhang \\ University of North Carolina at Chapel Hill \\ Yanshuang Peng \\ North Sichuan Medical University \\ Daqing Wang \\ North Sichuan Medical University \\ Ying Liu ( $\square$ liuying08_nsmz@163.com ) \\ North Sichuan Medical University https://orcid.org/0000-0003-0917-9716
}

\section{Research article}

Keywords: Periodontal bacteria; Neoplasms; Prognosis; Meta-analysis

Posted Date: September 30th, 2019

DOI: https://doi.org/10.21203/rs.2.15413/v1

License: @ (i) This work is licensed under a Creative Commons Attribution 4.0 International License. Read Full License

Version of Record: A version of this preprint was published at Medicine on April 1st, 2020. See the published version at https://doi.org/10.1097/MD.0000000000019698. 


\section{Abstract}

Background Periodontal bacteria is the major pathogens in the oral cavity and the main cause of adult chronic periodontitis, but their association with incidence and prognosis in cancer is controversial. The aim of this study was to evaluate the effect of periodontal bacteria infection on incidence and prognosis of cancer.Methods A systematic literature search of PubMed, Embase, Web of Science and Cochrane Library databases was performed to obtain 39 studies comprising 7184 participants. The incidence of cancer was evaluated as odd ratios (OR) with a 95\% confidence interval $(95 \% \mathrm{Cl})$ using Review Manager 5.2 software. Overall survival (OS), cancer-specific survival (CSS) and disease-free survival (DFS), which were measured as hazard ratios (HR) with a $95 \%$ confidence interval $(95 \% \mathrm{Cl})$ using Review Manager 5.2 software.Results Our results indicated that periodontal bacteria infection increased the incidence of cancer $(\mathrm{OR}=1.25 ; 95 \% \mathrm{Cl}: 1.03-1.52)$ and was associated with poor OS (HR $=1.75 ; 95 \% \mathrm{Cl}: 1.40-2.20), \mathrm{DFS}(\mathrm{HR}=2.18$; $95 \% \mathrm{Cl}: 1.24-3.84)$ and $\mathrm{CSS}(\mathrm{HR}=1.85,95 \% \mathrm{Cl}: 1.44-2.39)$. Subgroup analysis indicted that the risk of cancer was associated with Porphyromonas gingivalis $(\mathrm{Pg})$ infection $(\mathrm{OR}=2.16$; $95 \% \mathrm{Cl}: 1.34-3.47)$ and Prevotella intermedia $(\mathrm{Pi})$ infection (OR=1.28; $95 \% \mathrm{Cl}$ : 1.011.63) but not Tannerella forsythia (Tf) (OR=1.06; 95\% Cl: 0.8-1.41), Treponema denticola (Td) (OR=1.30; $95 \% \mathrm{Cl}: 0.99-1.72)$, Aggregatibacter actinomycetemcomitans $(\mathrm{Aa})(\mathrm{OR}=1.00 ; 95 \% \mathrm{Cl}$ : $0.48-2.08)$ and Fusobacterium nucleatum (Fn) $(\mathrm{OR}=0.61 ; 95 \% \mathrm{Cl}$ : 0.32-1.16).Conclusion This meta-analysis revealed periodontal bacteria infection increased the incidence of cancer and predicted poor prognosis of cancer.

\section{Background}

Cancer is the second leading cause of death globally and is estimated to account for 9.6 million death in 2018, according to new data from the world health organization (1). Epidemiological studies established several well-defined risk factors for cancer, including age, heredity, diet, tobacco use, chronic viral infections, and inflammation. However, the viewpoint that bacterial infections cause cancer has been ignored. Until 1994, helicobacter pylori, which is defined as a class I carcinogen, was associated with the development of cancer in humans (2). Since then there has been a growing number of evidence supporting an association between cancer and bacterial infection, including those in the oral cavity. Periodontal disease is one of the most common inflammatory diseases in adults. Periodontal bacteria, one of the most important causes of periodontal disease, which can lead to tooth loss and systemic inflammation, are associated with many systemic disorders such as cardiovascular diseases, diabetes, pulmonary diseases and rheumatoid arthritis (3). Recently, Mounting evidence suggests a causal relationship between periodontal bacteria infections and the development of malignancies. Several periodontal bacteria have been reported to be related with development of cancer, such as Pg and $\mathrm{Fn}(4,5,6)$. Furthermore, periodontal bacteria infection has been used as marker to evaluate the prognosis of cancer patients $(7,8$, 9). However, owing to difference in study method, sample size, study population and research region, the effect of periodontal bacteria infections on incidence and prognosis of cancer are unclear.

In this study, we performed a systematic review of the available literature on this topic in PubMed, Embase, Web of Science and the Cochrane Library. Then, we conducted a meta-analysis to determine the incidence and prognosis of periodontal bacteria in cancer, for purpose of addressing controversy.

\section{Methods}

\section{Literature search.}

Articles relevant with the subject were retrieved from PubMed, Embase, Web of Science and Cochrane Library databases on June 10, 2019. The search strategy was listed as follows: ((((cancer [Title/Abstract]) OR tumor [Title/Abstract]) OR malignancy [Title/Abstract]) OR carcinoma [Title/Abstract]) OR neoplasm [Title/Abstract]) AND (((((Porphyromonas gingivalis [Title/Abstract]) OR Fusobacterium nucleatum [Title/Abstract]) OR Tannerella forsythia [Title/Abstract]) OR Treponema denticola [Title/Abstract]) OR Aggregatibacter actinomycetemcomitans [Title/Abstract]) OR Prevotella intermedia [Title/Abstract]). Two reviewers (L.X. and Q.Y.Z.) inspected all candidate articles independently. Discrepancies were resolved by discussion with the senior authors (D.Q.W and Y.L.).

\section{Inclusion and exclusion criteria.}

The inclusion criteria were: (1) the diagnosis of cancer was confirmed by pathological examination; (2) Study designs must be prospective or retrospective cohort study. Studies must compare patients with periodontal bacteria infected and periodontal bacteria 
uninfected; (3) Studies must analyse the cancer incidence, OS, DFS and CSS in cancer patients; (4) Articles were published as original research.

The exclusion criteria were: (1) reviews, meeting abstracts, letters; (2) animal model studies.

\section{Data extraction and quality assessment}

Two reviewers (L.X and Q.Y.Z.) independently extracted following data and information from final studies : author, year of publication, types of periodontal bacteria, study country, sample size, survival data and the tumor location. The enrolled literatures were then qualified by PRISMA checklists (Supplementary Table 1). Disagreements were resolved by discussion. Two authors (Y.S.P \& L.X) assessed the final studies, scored them using the modified Newcastle-Ottawa Scale (NOS) and the scoring system was based on three categories: selection, comparability, and outcome. The full score was 8 points, and a high-quality study in our analysis was defined as a study with $\geq 7$ points. Consensus was reached by discussion with senior reviewers (Y.L. and D.Q.W).

\section{Statistical analysis}

Review Manager 5.2 (RevMan 5.2) was used to conduct all statistical analyses. Standard Cochran's $Q$ test and $R$ statistics were used to identify heterogeneity between the included studies. A value of $R$ statistics $>50 \%$ and $p$-value $<0.1$ indicated significant heterogeneity, therefore a random effects model was used to calculate the pooled OR, HR and $95 \% \mathrm{Cl}$ in such cases. Otherwise, a fixed effects model was applied. We used the mean sample size as the boundary between studies with large and small sample sizes. Publication bias was detected with the Begg and Egger's regression intercept test by using STATA 12. A two-tailed $P$ value $<0.05$ was considered statistically significant.

\section{Results}

\section{Study characteristics}

The process used to select the studies included in this article is summarized in Figure 1. From an initial 1194 potentially relevant articles, the duplicate studies was removed and we screened titles and abstracts of articles. Finally, a total of 18 articles including 39 studies and 7264 participants were enrolled in the meta-analysis. The detailed characteristics of the selected studies are presented in Table 1. The selected articles were published from 2013 to 2018, and all articles were evaluated by the NOS (Supplementary Table 2). There were 9, 8,4 and 3 articles related with incidence, OS, DFS, and CSS, respectively. 16 studies were conducted in Asia, 19 in North America and 3 in Europe. Among the 38 included studies, 10 studies involved patients with Pg infection, 15 with Fn infection, 5 with Tf infection, 3 with Aa infection, 3 with Td in infection and 2 with Pi infection. The sample sizes of the included studies ranged from 80 to 1069. According to the mean of all samples, 12 studies were considered to have a large sample size $(n>467)$, while 11 had a small sample size $(n \leq 467)$.

\section{Periodontal bacteria and incidence of cancer}

23 studies with 10736 patients reported the relationship between periodontal bacteria and incidence of cancer (Figure 2). Periodontal bacteria infection increased the incidence of cancer as much as 1.25 times compared with those no infecting with periodontal bacteria (OR=1.25, 95\% Cl: $1.03-1.52, P=0.02)$ although with heterogeneity $\left({ }^{2}=71 \%, P_{h}<0.00001\right)$. The subgroup studies consisted of different periodontal bacteria, ethnicity of participants, tumor location and sample size (Table 2). In our subgroup analysis, individuals whose infected with $\mathrm{Pg}$ were at 2.16 times greater risk of developing cancer than those no infecting with $\mathrm{Pg}(\mathrm{OR}=2.16$, 95\%Cl: $\left.1.34-3.47 ; P=0.001 ; P^{2}=79 \%, P_{h}<0.0001\right)$. Individuals with $\mathrm{Pi}$ infection exhibit increased incidence of cancer (OR=1.28; $95 \% \mathrm{Cl}$ : 1.01-1.63; $P=0.04)$. However, there was no significant relation between the infection of $\mathrm{Tf}(\mathrm{OR}=1.06,95 \% \mathrm{Cl}: 0.8-1.41, P=0.67$; $\left.P^{2}=41 \%, P_{h}=0.15\right)$, Aa (OR=1.00, 95\% Cl: $\left.0.48-2.08, P=1.00 ; P^{2}=80 \%, P_{h}=0.006\right)$, Td (OR=1.30, 95\%Cl: $0.99-1.72, P=0.06 ; P^{2}=6 \%, P_{h}$ $=0.35), \mathrm{Fn}\left(\mathrm{OR}=0.61 ; 95 \% \mathrm{Cl}: 0.32-1.16 ; P=0.13 ; P=0 \%, P_{h}=0.68\right)$ and incidence of cancer. There was association in Asia (OR=2.59, 95\%Cl:1.65-4.05, $\left.P<0.0001 ; P^{2}=94 \%, P_{h}<0.00001\right)$ and Caucasian (OR=1.19, 95\%Cl:1.03-1.36, $\left.P=0.02 ; P^{2}=44 \%, P_{h}=0.02\right)$ between periodontal bacteria infection and incidence of cancer. In the subgroup analysis of tumor location, incidence of cancer was associated with periodontal bacteria infection in OSCC (OR=10.02, 95\%Cl:3.11-32.33, $P<0.0001)$ but not EC (OR=1.73, 95\%Cl:0.80-3.73, $P=0.17$; $\left.P^{2}=82 \%, P_{h}=0.0007\right), \mathrm{PC}\left(\mathrm{OR}=1.21,95 \% \mathrm{Cl}: 0.96-1.53, P=0.1 ; P^{2}=61 \%, P_{h}=0.02\right), \mathrm{PLGC}\left(\mathrm{OR}=0.69,95 \% \mathrm{Cl}: 0.37-1.29, P=0.24 ; P^{2}=48 \%\right.$, 
$\left.P_{h}=0.12\right)$ and $\mathrm{CRC}\left(\mathrm{OR}=1.26,95 \% \mathrm{Cl}: 1.00-1.57, P=0.05 ; P^{2}=42 \%, P_{h}=0.12\right)$. According to the subgroup analysis of the sample size, periodontal bacteria infection were related to incidence of cancer in large sample size (OR=1.26,95\%Cl:1.08-1.46, $P=0.003 ; P=46 \%$, $\left.P_{h}=0.04\right)$, but not in small sample size (OR=1.24, 95\%Cl:0.73-2.12, $\left.P=0.42 ; R=42 \%, P_{h}<0.00001\right)$.

\section{Periodontal bacteria and OS in cancer}

Figure 3a indicates that OS of cancer patients was evaluated in 8 studies with 3289 patients. The HR for OS in cancer patients infecting with periodontal bacteria compared with those no infecting with periodontal bacteria was 1.75 times $(95 \% \mathrm{Cl}: 1.40-2.20, P$ $<0.00001)$. The result revealed periodontal bacteria infection was related to poor OS in cancer. There was little heterogeneity between studies $\left(R=0 \%, P_{h}=0.79\right)$. The subgroup analysis involved in different periodontal bacteria (Mainly Pg and Fn), ethnicity of participants , tumor location and sample size (Table 3). In the subgroup, both of $\mathrm{Pg}$ and Fn infection was correlated with poor OS in cancer (Pg: HR=4.04, 95\% Cl: 1.54-10.63, $P=0.05 ; \mathrm{Fn}: \mathrm{HR}=1.67,95 \% \mathrm{Cl}: 1.32-2.11, P<0.0001)$. There was little heterogeneity between studies (Pg: $P^{2}=0 \%, P_{h}=0.64 ; \mathrm{Fn}: P^{2}=0 \%, P_{h}=0.99$ ). Periodontal bacteria infection was correlated with poor OS of cancer patients in Asia (HR=1.90,95\%Cl:1.43-2.53, $\left.P<0.0001 ; I^{2}=0 \%, P_{h}=0.70\right)$ and Caucasian (HR=1.53, 95\%Cl:1.05-2.23, $\left.P=0.03 ; P^{2}=0 \%, P_{h}=0.77\right)$. In the subgroup of tumor location, there were consistent findings in EC ( $\left.\mathrm{HR}=2.13,95 \% \mathrm{Cl}: 1.36-3.35, P=0.0010 ; P^{2}=15 \%, P_{h}=0.31\right)$ and $\mathrm{CRC}$ (HR=1.64,95\%Cl:1.26-2.13, $\left.P=0.0002 ; P=0 \%, P_{h}=0.97\right)$. According to the subgroup analysis of sample size, periodontal bacteria infection exhibited a trend of correlation with poor OS in large ( $\left.\mathrm{HR}=1.53,95 \% \mathrm{Cl}: 1.05-2.23, P=0.03 ; P=0 \%, P_{h}=0.77\right)$ and small sample size (HR=1.90, 95\% Cl:1.43-2.53, $\left.P<0.0001 ; P^{2}=0 \%, P_{h}=0.70\right)$.

\section{Periodontal bacteria and DFS in cancer}

Figure $3 \mathbf{b}$ shows the results of DFS of cancer patients in 5 studies with 1384 patients. The HR for DFS in cancer patients infecting with periodontal bacteria compared with those not periodontal bacteria was 2.18 times (95\% Cl: $1.24-3.84, P=0.007)$. The result revealed there was significant association between periodontal bacteria infection and poor DFS in cancer. Interstudy heterogeneity was noted $\left(R^{2}=81 \%, P_{h}=0.0003\right)$. The subgroup studies involved in types of periodontal bacteria, ethnicity of participants , tumor location and sample size (Table 3).

\section{Periodontal bacteria and CSS in cancer}

The association of periodontal bacteria infection and DFS in cancer was supplied by 3 studies with 1674 patients (Figure 3c). Data analysis showed that the periodontal bacteria infection was related to poor CSS (HR $=1.85,95 \%$ Cl: $1.44-2.39, P<0.00001)$ without obvious heterogeneity $\left(R^{2}=0 \%, P_{h}=0.51\right)$.

\section{Heterogeneity and sensitivity analysis}

There was evidence of significant heterogeneity in incidence of cancer $\left(R=71 \%, P_{h}<0.00001\right)$ and DFS $\left(R=81 \%, P_{h}=0.0003\right)$ but not OS $\left(R=0 \%, P_{h}=0.79\right)$ and CSS $\left(P^{2}=0 \%, P_{h}=0.51\right)$. Subgroup analyses detecting potential sources of heterogeneity indicated that different periodontal bacteria, ethnicity of participants, tumor location and sample size were not significantly correlated with the heterogeneity in this meta-analysis. We found that Gao 2016 study was the source of heterogeneity in the meta-analysis for incidence of cancer and Oh 2018 for DFS. After removing Gao 2016 and Oh 2018, the heterogeneity among the studies decreased slightly for incidence of cancer $\left(R=64 \%, P_{h}<0.0001\right)$, but decreased significantly for DFS ( $\left.R=62 \%, P_{h}=0.05\right)$, and the result for incidence of cancer (OR=1.21, 95\% Cl: 1.02-1.44, $P=0.03$ ) (Supplementary Figure 1) and DFS (HR=2.79, 95\%Cl: 1.72-4.54, $P<0.0001$ )

(Supplementary Figure 2) followed the same trends as those in the previous analysis. We also performed a sensitivity analysis through removing low-quality studies (NOS<7). The result for incidence of cancer ( $\mathrm{OR}=1.29,95 \% \mathrm{Cl}: 1.08-1.53, P=0.005)$

(Supplementary Figure 3), OS (OR=1.67, 95\%Cl: 1.28-2.18, $P=0.0002)$ (Supplementary Figure 4), DFS (HR=2.34, 95\% Cl: 1.28-4.28, $P=0.006$ ) (Supplementary Figure 5) followed the same trends as those in the previous analysis.

\section{Publication Bias}

The results of the risk of bias assessment are shown in figure 4a, $\mathbf{4 b}$. Egger's and Begg's tests indicated the potential publication bias for incidence (0.092) and prognosis (including OS, DFS and CSS: 0.624) of cancer. There was no significant publication bias in these studies. 


\section{Discussion}

There is increasing evidence that bacteria play an important role in tumorigenesis by activating chronic inflammation (25). Chronic inflammation and infections are increasingly identified as an important epidemiologic and environmental factor in cancer development. There is considerable evidence that proves the interrelationship between bacterial infections and carcinogenesis, such as helicobacter pylori for gastric cancer (26), human papilloma virus for cervical cancer (27) and Fn for CRC (28). The relationship between periodontal bacteria and inflammation has attracted the attention from researchers due to the potential influence of periodontitis on initiation and/or progression of several systemic diseases, including cancer (3). Therefore, many recent studies explore the interrelationship between periodontal bacteria, inflammation, and cancer $(29 ; 30 ; 31)$. However, no consensus has been reached on the effects of periodontal bacteria on incidence and prognosis of cancer.

In this meta-analysis, 38 studies including 7184 patients were involved, and we summarized the associations between 6 periodontal bacteria and incidence and prognosis of cancer. The infection of 6 periodontal bacteria was found to increase incidence of cancer and the risk of cancer as much as 1.25 times compared with uninfected patients. Further, the infection of 6 periodontal bacteria was a considerable prognostic factor for poor OS, DFS and CSS. However, in our subgroup analysis, infection of Fn had no significant effect on incidence of cancer. According to numerous current study reports, Fn was tightly related to the occurrence and development of gastrointestinal cancer $(32 ; 33 ; 34)$. Moreover, in our subgroup of OS, Fn was associated with poor OS in cancer patients. Because the sample sizes about incidence of cancer are relatively limited, our results require careful interpretation.

Subgroup analysis of cancer incidence showed that infection Pg increased risk of cancer as much as 2.16 times compared with uninfected patients. In line with our results, it has been reported that infection Pg was is a significant risk factor for various malignancies including orodigestive cancers, gastrointestinal cancer, and even prostate cancer $(35 ; 36 ; 37)$. Previous study showed that $\mathrm{Pg}$ can promote the development of orodigestive cancers by inducing epithelial-to-mesenchymal transition, activating metalloproteinase-9 and interleukin-8 and accelerating cell cycling and suppressing apoptosis (36). In our results, there was no significant relationship between infection of $\mathrm{Tf}, \mathrm{Aa}, \mathrm{Td}$ and $\mathrm{Fn}$ and incidence of cancer. Previous studies indicated that $\mathrm{Tf}, \mathrm{Aa}$ and $\mathrm{Td}$ had a positive effect on progression of cancer $(38 ; 39 ; 40)$. It is pity that the number of related studies are limited. These results hinted that more studies are needed to determine whether the infection of these periodontal bacteria can influence the incidence of cancer.

Subgroup analysis of OS and DFS suggested that infection of Pg and Fn predicted a poor prognosis in cancer patients. Similarly, current study reported that both Pg and Fn had attributes consistent with a role in cancer development and progression (41). Moreover, there is extensive evidence showing that $\mathrm{Pg}$ and $\mathrm{Fn}$ are abundant in tumors and activate transduction pathways, such as anti-apoptotic pathway and nuclear factor-KB, leading to poor prognosis of cancer (42;43). In addition, the subgroup analysis of tumor location indicated that periodontal bacteria infection was correlated with a poor prognosis in patients with EC and CRC. Recently studies in animals and man have indicated that oral bacteria can influence the prognosis of patients with digestive system cancers including EC and CRC by perpetuating inflammation, regulating the immune system-microbe-tumor axis, affecting metabolism, and altering the tumor microenvironment (44) .

Although we have conducted a comprehensive search and systematic analysis of the relevant studies, inevitably, this meta-analysis has the following limitations. Firstly the number of included studies about Aa, $\mathrm{Td}$ and $\mathrm{Pi}$ are relatively small. Secondly, the overall heterogeneity was high, so random effects models were required for the analysis. Finally, the study populations were all of Asian or Caucasian ethnicity, which may have caused a population selection bias.

\section{Conclusions}

This meta-analysis suggested that different periodontal bacteria infection correlated with different incidence of cancer: $\mathrm{Pg}$ and $\mathrm{Pi}$ infection was associated with high incidence of cancer, while there are no obvious relationship between the Tf, Aa, Td and Fn infection and incidence of cancer. Furthermore, our study revealed that the infection of periodontal bacteria, mainly Pg and Fn, predicted poor OS, DFS and CSS in cancer patients. Our meta-analysis hinted that improvement of oral hygiene and treatment of periodontal disease should also be taken into consideration in the prevention and treatment strategies for cancer.

\section{Abbreviations}

odd ratios $\mathrm{OR}$ 
$95 \%$ confidence interval $95 \% \mathrm{Cl}$

Overall survival OS

cancer-specific survival CSS

disease-free survival DFS

hazard ratios $\mathrm{HR}$

Porphyromonas gingivalis $\mathrm{Pg}$

Prevotella intermedia $\mathrm{Pi}$

Tannerella forsythia $\mathrm{Tf}$

Treponema denticola $\mathrm{Td}$

Aggregatibacter actinomycetemcomitans $\mathrm{Aa}$

Fusobacterium nucleatum Fn

\section{Declarations}

\section{Ethics approval and consent to participate}

Not applicable.

\section{Consent for publication}

Not applicable.

\section{Availability of data and materials}

All data analyzed during this study are included in this published article.

\section{Competing interests}

The authors declare that they have no competing interests.

\section{Funding}

This work was supported by the Special Fund for Municipal and University Cooperative Scientific Research (no.: 18SXHZ0270), the Scientific Research Project of Guangdong Provincial Key Oral Medicine Laboratory (no.: KF2016120103) and the Doctor of North Sichuan Medical College Fund (no. : CBY13-QD-07. The funding bodies had no role in the design of the study and collection, analysis, and interpretation of data and in writing the manuscript.

\section{Authors' contributions}

Two reviewers (L.X and Q.Y.Z) independently extracted data and information from final studies. Two authors (Y.S.P \&L.X) assessed the final studies, scored them using the NOS and consensus was reached by discussion with senior reviewers (Y.L. and D.Q.W.) .

\section{Acknowledgements}

We are grateful to all researchers of enrolled studies.

\section{Authors' Information}

Li Xiao, Email: 960127792@qq.com 
Qianyu Zhang, Email: 634816128@qq.com

Yanshuang Peng, Email: 1799486941@qq.com

Daqing Wang, Email:Wdq11@sina.com

Ying Liu, Email: liuying08_nsmz@163.com

\section{References}

1. WHO. The International Agency for Research on Cancer. 2018. https://www.who.int/cancer/en/. Accessed on 5 December 2018.

2. Kim SS, Ruiz VE, Carroll JD, Moss SF. Helicobacter pylori in the pathogenesis of gastric cancer and gastric lymphoma. Cancer Lett. 2011;305: 228-238. doi: 10.1016/j.canlet.2010.07.014.

3. Bui FQ et al. Association between periodontal pathogens and systemic disease. Biomed J. 2019;42(1):27-35. doi:10.1016/j.bj.2018.12.001.

4. Galvão-Moreira LV, da Cruz MC. Oral microbiome, periodontitis and risk of head and neck cancer. Oral Oncol. 2016; 53:17-9. doi:10.1016/j.oraloncology.2015.11.013.

5. Karpiński TM. Role of Oral Microbiota in Cancer Development. Microorganisms. 2019;7(1). pii: E20. doi.:10.3390/microorganisms7010020.

6. Komiya $Y$ et al. Patients with colorectal cancer have identical strains of Fusobacterium nucleatum in their colorectal cancer and oral cavity. Gut. 2018;68(7):1335-1337. doi:10.1136/gutjnl-2018-316661.

7. Gao S et al. Presence of Porphyromonas gingivalis in esophagus and its association with the clinicopathological characteristics and survival in patients with esophageal cancer. Infect Agent Cancer. 2016;11:3. doi: 10.1186/s13027-016-0049-x.

8. Mima K et al. Fusobacterium nucleatum in colorectal carcinoma tissue and patient prognosis. Gut. 2016;65(12):1973-1980. doi:10.1136/gutjnl-2015-310101.

9. Yu T et al. Fusobacterium nucleatum Promotes Chemoresistance to Colorectal Cancer by Modulating Autophagy. Cell. 2017;170(3):548-563.e16. doi:10.1016/j.cell.2017.07.008.

10. Peters BA et al. Oral Microbiome Composition Reflects Prospective Risk for Esophageal Cancers. Cancer Res. 2017; 77(23):67776787. doi:10.1158/0008-5472.CAN-17-1296.

11. Fan X et al. Human oral microbiome and prospective risk for pancreatic cancer: a population-based nested case-control study. Gut. 2018;67(1):120-127. doi:10.1136/gutjnl-2016-312580.

12. Michaud DS et al. Plasma antibodies to oral bacteria and risk of pancreatic cancer in a large European prospective cohort study. Gut. 2013;62(12):1764-70. doi:10.1136/gutjnl-2012-303006.

13. Sun J et al. Chronic Periodontal Disease, Periodontal Pathogen Colonization, and Increased Risk of Precancerous Gastric Lesions. J Periodontol. 2017;88(11):1124-1134.

doi: 10.1902/jop.2017.160829.

14. Yang $Y$ et al. Prospective study of oral microbiome and colorectal cancer risk in low-income and African American populations. Int J Cancer. 2019;144(10):2381-2389. doi:10.1002/ijc.31941.

15. Chang $\mathrm{C}$ et al. The prevalence rate of periodontal pathogens and its association with oral squamous cell carcinoma. Appl Microbiol Biotechnol. 2019;103(3):1393-1404.

doi:10.1007/s00253-018-9475-6.

Page 7/15 
16. Yuan $\mathrm{X}$ et al. Different frequencies of Porphyromonas gingivalis infection in cancers of the upper digestive tract. Cancer Lett. 2017; 404:1-7. doi:10.1016/j.canlet.2017.07.003.

17. Gao SG et al. Preoperative serum immunoglobulin $\mathrm{G}$ and $\mathrm{A}$ antibodies to Porphyromonas gingivalis are potential serum biomarkers for the diagnosis and prognosis of esophageal squamous cell carcinoma. BMC Cancer.

2018;18(1):17.doi:10.1186/s12885-017-3905-1.

18. Yamaoka $Y$ et al. Fusobacterium nucleatum as a prognostic marker of colorectal cancer in a Japanese population. J Gastroenterol. 2018;53(4):517-524. doi:10.1007/s00535-017-1382-6.

19. Wei $Z$ et al. Could gut microbiota serve as prognostic biomarker associated with colorectal cancer patients' survival? A pilot study on relevant mechanism. Oncotarget. 2016;7(29):46158-46172.

doi:10.18632/oncotarget.10064.

20. Yamamura $\mathrm{K}$ et al. Human Microbiome Fusobacterium Nucleatum in Esophageal Cancer Tissue Is Associated with Prognosis. Clin Cancer Res. 2016;22(22):5574-5581.

doi:10.1158/1078-0432.CCR-16-1786.

21. Lee DW et al. Association Between Fusobacterium nucleatum, Pathway Mutation, and Patient Prognosis in Colorectal Cancer. Ann Surg Oncol. 2018;25(11):3389-3395.

doi:10.1245/s10434-018-6681-5.

22. Liu L e al. Diets That Promote Colon Inflammation Associate With Risk of Colorectal Carcinomas That Contain Fusobacterium nucleatum. Clin Gastroenterol Hepatol. 2018; 16(10):1622-1631.

doi:10.1016/j.cgh.2018.04.030.

23. Yan X, Liu L, Li H, Qin H, Sun Z. Clinical significance of Fusobacterium nucleatum, epithelial-mesenchymal transition, and cancer stem cell markers in stage III/IV colorectal cancer patients. Onco Targets Ther. 2017;10:5031-5046. doi:10.2147/OTT.S145949.

24. Oh et al. Prognostic Impact of Fusobacterium nucleatum Depends on Combined Tumor Location and Microsatellite Instability Status in Stage II/III Colorectal Cancers Treated with Adjuvant Chemotherapy. J Pathol Transl Med. 2019;53(1):40-49.

doi:10.4132/jptm.2018.11.29.

25. Francescone R, Hou V, Grivennikov SI. Microbiome, inflammation, and cancer. Cancer J. 2014;20(3):181-

189.doi:10.1097/PPO.0000000000000048.

26. Wroblewski LE, Peek RM Jr. Helicobacter pylori, Cancer, and the Gastric Microbiota. Adv Exp Med Biol. 2016;908:393-408.

doi:10.1007/978-3-319-41388-4_19.

27. So KA et al. Human papillomavirus genotype-specific risk in cervical carcinogenesis. J Gynecol Oncol. 2019;30(4):e52.

doi:10.3802/jgo.2019.30.e52.

28. Shang FM, Liu HL. Fusobacterium nucleatum and colorectal cancer: A review. World J Gastrointest Oncol. 2018;10(3):71-81. doi:10.4251/wjgo.v10.i3.71.

29. Hoare A, Soto C, Rojas-Celis V, Bravo D. Chronic Inflammation as a Link between Periodontitis and Carcinogenesis. Mediators Inflamm 2019:1029857. doi:10.1155/2019/1029857.

30. Zambirinis CP, Pushalkar S, Saxena D, Miller G.Pancreatic cancer, inflammation, and microbiome. Cancer J. 2014;20(3):195-202. doi:10.1097/PP0.0000000000000045.

31. Shrihari TG, Vasudevan V, Manjunath V, Devaraju D. Potential Co-Relation Between Chronic Periodontitis And Cancer - An Emerging Concept. Gulf J Oncolog. 2016;1(20):20-24. 
32. Proença MA et al. Relationship between Fusobacterium nucleatum, inflammatory mediators and microRNAs in colorectal carcinogenesis. World J Gastroenterol. 2018;24(47):5351-5365.

doi:10.3748/wjg.v24.i47.5351.

33. Liu Y et al. Progress in characterizing the linkage between Fusobacterium nucleatum and gastrointestinal cancer. J Gastroenterol. 2019;54(1):33-41. doi:10.1007/s00535-018-1512-9.

34. Bullman S et al. Analysis of Fusobacterium persistence and antibiotic response in colorectal cancer. Science. 2017; 358(6369):1443-1448. doi:10.1126/science.aal5240.

35. Ahn J, Segers S, Hayes RB. Periodontal disease, Porphyromonas gingivalis serum antibody levels and orodigestive cancer mortality. Carcinogenesis. 2012;33(5):1055-1058.

doi:10.1093/carcin/bgs112.

36. Olsen I, Yilmaz Ö. Possible role of Porphyromonas gingivalis in orodigestive cancers. J Oral Microbiol. 2019;11(1):1563410. doi:10.1080/20002297.2018.1563410.

37. da Silva APB, Alluri LSC, Bissada NF, Gupta S. Association between oral pathogens and prostate cancer: building the relationship. Am J Clin Exp Urol. 2019;7(1):1-10.

38. Malinowski B et al. The role of Tannerella forsythia and Porphyromonas gingivalis in pathogenesis of esophageal cancer. Infect Agent Cancer. 2018; 14:3. doi:10.1186/s13027-019-0220-2.

39. Zhu B, Macleod LC, Newsome E, Liu J, Xu P. Aggregatibacter actinomycetemcomitans mediates protection of Porphyromonas gingivalis from Streptococcus sanguinis hydrogen peroxide production in multi-species biofilms. Sci Rep. 2019;9(1):4944.

doi:10.1038/s41598-019-41467-9.

40. Nieminen MT et al. Treponema denticola chymotrypsin-like proteinase may contribute to orodigestive carcinogenesis through immunomodulation. Br J Cancer. 2018;118(3):428-434.

doi:10.1038/bjc.2017.409.

41. Sarah E. Whitmore, Richard J. Lamont. Oral Bacteria and Cancer. PLoS Pathog. 2014;10(3): e1003933. doi:10.1371/journal.ppat.1003933.

42. Arjunan P et al. Oral Pathobiont Activates Anti-Apoptotic Pathway, Promoting both Immune Suppression and Oncogenic Cell Proliferation. Sci Rep. 2018;8(1):16607. doi:10.1038/s41598-018-35126-8.

43. Yang $Y$ et al. Fusobacterium nucleatum Increases Proliferation of Colorectal Cancer Cells and Tumor Development in Mice by Activating Toll-Like Receptor 4 Signaling to Nuclear Factor-KB, and Up-regulating Expression of MicroRNA-21. Gastroenterology. 2017;152(4):851-866.

doi:10.1053/j.gastro.2016.11.018.

44. Yasusei Kudo et al. Oral environment and cancer. Genes Environ. 2016;38:13. doi:10.1186/s41021-016-0042-z.

\section{Tables}

Table 1. Characteristics of included studies. 


\begin{tabular}{|c|c|c|c|c|c|c|c|c|c|c|}
\hline $\begin{array}{l}\text { Author } \\
\text { year }\end{array}$ & $\begin{array}{l}\text { Target } \\
\text { bacterium }\end{array}$ & Country & Ethnicity & $\begin{array}{l}\text { Type of } \\
\text { cancer }\end{array}$ & $\begin{array}{l}\text { Sample size } \\
\text { (cases/controls) }\end{array}$ & Samples & $\begin{array}{l}\text { Detection } \\
\text { method }\end{array}$ & Outcome & $\begin{array}{l}\text { Study } \\
\text { design }\end{array}$ & $\begin{array}{l}\text { NOS } \\
\text { score }\end{array}$ \\
\hline $\begin{array}{l}\text { Peters et } \\
\text { al (10) }\end{array}$ & $\mathrm{Pg} / \mathrm{Tf} / \mathrm{Td}$ & USA & $\begin{array}{l}\text { North } \\
\text { America }\end{array}$ & EAC/ESCC & $316(106 / 210)$ & mouthwash & $\begin{array}{l}\text { 16sRNA } \\
\text { gene } \\
\text { sequencing }\end{array}$ & Incidence & $\mathrm{P}$ & 7 \\
\hline $\begin{array}{l}\text { Fan et al } \\
(11)\end{array}$ & $\mathrm{Pg} / \mathrm{Aa} / \mathrm{Tf} / \mathrm{Pi}$ & USA & $\begin{array}{l}\text { North } \\
\text { America }\end{array}$ & $\mathrm{PC}$ & $732(361 / 371)$ & mouthwash & $\begin{array}{l}\text { 16sRNA } \\
\text { gene } \\
\text { sequencing }\end{array}$ & Incidence & $\mathrm{P}$ & 7 \\
\hline $\begin{array}{l}\text { Michaud } \\
\text { et al (12) }\end{array}$ & $\mathrm{Pg} / \mathrm{Aa} / \mathrm{Tf}$ & EPIC & Europe & $\mathrm{PC}$ & $821(405 / 416)$ & blood & $\begin{array}{l}\text { immunoblot } \\
\text { array }\end{array}$ & Incidence & $\mathrm{P}$ & 7 \\
\hline $\begin{array}{l}\text { Sun et al } \\
\text { (13) }\end{array}$ & $\mathrm{Pg} / \mathrm{Tf} / \mathrm{Td} / \mathrm{Aa}$ & USA & $\begin{array}{l}\text { North } \\
\text { America }\end{array}$ & PLGC & $105(35 / 70)$ & saliva & qPCR & Incidence & $\mathrm{R}$ & 6 \\
\hline $\begin{array}{l}\text { Yang et al } \\
\text { (14) }\end{array}$ & $\mathrm{Pg} / \mathrm{Tf} / \mathrm{Td} / \mathrm{Pi} / \mathrm{Fn}$ & USA & $\begin{array}{l}\text { North } \\
\text { America }\end{array}$ & CRC & $692(231 / 461)$ & $\begin{array}{l}\text { mouth } \\
\text { rinse }\end{array}$ & $\begin{array}{l}\text { 16sRNA } \\
\text { gene } \\
\text { sequencing }\end{array}$ & Incidence & $\mathrm{P}$ & 6 \\
\hline $\begin{array}{l}\text { Chang et } \\
\text { al (15) }\end{array}$ & $\mathrm{Pg}$ & China & Asia & OSCC & $91(61 / 30)$ & tissue & qPCR & Incidence & $\mathrm{R}$ & 5 \\
\hline $\begin{array}{l}\text { Yuan et al } \\
(16)\end{array}$ & $\mathrm{Pg}$ & China & Asia & EC & $80(50 / 30)$ & tissue & qPCR & Incidence & $\mathrm{R}$ & 6 \\
\hline $\begin{array}{l}\text { Gao et al } \\
(17)\end{array}$ & $\mathrm{Pg}$ & China & Asia & ESCC & $130(100 / 30)$ & tissue & qPCR & $\begin{array}{l}\text { Incidence } \\
\text { /OS }\end{array}$ & $\mathrm{P}$ & 6 \\
\hline $\begin{array}{l}\text { Yamaoka } \\
\text { et al (18) }\end{array}$ & Fn & Japan & Asia & $\mathrm{CRC}$ & $172(100 / 72)$ & tissue & $\begin{array}{l}\text { droplet } \\
\text { digital PCR }\end{array}$ & $\begin{array}{l}\text { Incidence } \\
\text { /OS }\end{array}$ & $\mathrm{P}$ & 7 \\
\hline $\begin{array}{l}\text { Gao et al } \\
\text { (7) }\end{array}$ & $\mathrm{Pg}$ & China & Asia & ESCC & 216 & serum & Elisa & OS & $\mathrm{P}$ & 4 \\
\hline $\begin{array}{l}\text { Wei et al } \\
\text { (19) }\end{array}$ & Fn & China & Asia & CRC & 180 & tissue & $\begin{array}{l}\text { 16sRNA } \\
\text { gene } \\
\text { sequencing }\end{array}$ & OS & $P$ & 6 \\
\hline $\begin{array}{l}\text { Yamamura } \\
\text { et al (20) }\end{array}$ & Fn & Japan & Asia & EC & 325 & tissue & $\mathrm{qPCR}$ & $\mathrm{CSS} / \mathrm{OS}$ & $\mathrm{P}$ & 6 \\
\hline $\begin{array}{l}\text { Lee et al } \\
(21)\end{array}$ & Fn & $\begin{array}{l}\text { South } \\
\text { Korea }\end{array}$ & Asia & CRC & 246 & tissue & qPCR & DFS/OS & $\mathrm{P}$ & 6 \\
\hline $\begin{array}{l}\text { Liu et al } \\
(22)\end{array}$ & Fn & USA & $\begin{array}{l}\text { North } \\
\text { America }\end{array}$ & CRC & 951 & tissue & qPCR & OS & $\mathrm{P}$ & 7 \\
\hline $\begin{array}{l}\text { Yan et al } \\
(23)\end{array}$ & $\mathrm{Fn}$ & China & Asian & CRC & 280 & tissue & qPCR & CSS/DFS & $\mathrm{P}$ & 6 \\
\hline $\begin{array}{l}\text { Mima et al } \\
\text { (8) }\end{array}$ & Fn & USA & $\begin{array}{l}\text { North } \\
\text { America }\end{array}$ & CRC & 1069 & tissue & qPCR & $\mathrm{CSS} / \mathrm{OS}$ & $\mathrm{p}$ & 7 \\
\hline $\begin{array}{l}\text { Oh et al } \\
(24)\end{array}$ & Fn & $\begin{array}{l}\text { South } \\
\text { Korea }\end{array}$ & Asia & CRC & 593 & tissue & qPCR & DFS & $\mathrm{P}$ & 6 \\
\hline $\begin{array}{l}\text { Yu et al } \\
(9)\end{array}$ & Fn & China & Asia & $\mathrm{CRC}$ & $\begin{array}{l}\text { Cohort1:92 } \\
\text { Cohort2: } 173\end{array}$ & tissue & qPCR & DFS & $\mathrm{P}$ & 6 \\
\hline
\end{tabular}

Pg: Porphyromonas gingivalis; Tf: Tannerella forsythia; Td: Treponema denticola; Aa: Aggregatibacter actinomycetemcomitans; Pi: Prevotella intermedia; Fn: Fusobacterium nucleatum. NOS: Newcastle-Ottawa Quality Assessment Scale; OS: overall survival; DFS: disease free survival; DSS: disease; CSS: cancer specific survival; EAC: esophageal adenocarcinoma; ESCC: esophageal squamous cell carcinoma; PC: pancreatic cancer; PLGC: precancerous lesions of gastric cancer; CRC: colorectal cancer; EC: esophageal cancer; EPIC: European Prospective Investigation into Cancer and Nutrition study, within 10 European countries (Denmark, France, Germany, Greece, Italy, the Netherlands, Norway, Spain, Sweden, and the United Kingdom). P: Prospective Cohort; R: Retrospective Cohort.

Table 2 Subgroup analysis results for periodontal bacteria on incidence of cancer. 


\begin{tabular}{|c|c|c|c|c|c|c|}
\hline & \multirow[t]{2}{*}{ Study NO. } & \multirow[t]{2}{*}{ Sample size } & \multirow[t]{2}{*}{ OR(95\%CI) } & \multirow[t]{2}{*}{$P$ value } & \multicolumn{2}{|c|}{ Heterogeneity } \\
\hline & & & & & $\mathrm{I}^{2}$ & $P$ value \\
\hline overall & 23 & 10656 & $1.22 \llbracket 1.01,1.47 \square$ & 0.02 & $70 \%$ & $<0.00001$ \\
\hline \multicolumn{7}{|c|}{ periodontal bacteria } \\
\hline $\mathrm{Pg}$ & 8 & 299 & $1.86(1.20,2.88)$ & 0.005 & $79 \%$ & $<0.0001$ \\
\hline $\mathrm{Tf}$ & 5 & 2711 & $1.06(0.80,1.41)$ & 0.67 & $41 \%$ & 0.15 \\
\hline $\mathrm{Aa}$ & 3 & 1658 & $1.00(0.48,2.08)$ & 1.00 & $80 \%$ & 0.006 \\
\hline $\mathrm{Td}$ & 3 & 1113 & $1.30(0.99,1.72)$ & 0.06 & $6 \%$ & 0.35 \\
\hline Fn & 2 & 864 & $0.61(0.32,1.16)$ & 0.13 & $0 \%$ & 0.68 \\
\hline$\overline{\mathrm{Pi}}$ & 2 & 1424 & $1.28(1.01,1.63)$ & 0.04 & $0 \%$ & 0.92 \\
\hline \multicolumn{7}{|l|}{ Ethnicity } \\
\hline Asia & 4 & 392 & $2.59(1.65,4.05 \square$ & $<0.0001$ & $94 \%$ & $<0.00001$ \\
\hline Caucasian & 19 & 10219 & $1.19(1.03,1.36)$ & 0.02 & $44 \%$ & 0.02 \\
\hline \multicolumn{7}{|c|}{ Tumor location } \\
\hline OSCC & 1 & 91 & $10.02(3.11,32.33)$ & 0.0001 & - & - \\
\hline EC & 5 & 1077 & $1.73(0.80,3.73 \square$ & 0.17 & $82 \%$ & 0.0007 \\
\hline $\mathrm{PC}$ & 7 & 5391 & $1.21(0.96,1.53 \square$ & 0.1 & $61 \%$ & 0.02 \\
\hline PLGC & 4 & 420 & $0.69(0.37,1.29)$ & 0.24 & $48 \%$ & 0.12 \\
\hline CRC & 6 & 3632 & $1.26(1.00,1.57)$ & 0.05 & $42 \%$ & 0.12 \\
\hline \multicolumn{7}{|c|}{ Sample size } \\
\hline Large & 12 & 8851 & $1.26(1.08,1.46)$ & 0.003 & $46 \%$ & 0.04 \\
\hline Small & 11 & 1760 & $1.24(0.73,2.12)$ & 0.42 & $80 \%$ & $<0.00001$ \\
\hline
\end{tabular}

Table 3 Subgroup analysis results for Pg and Fn infection on the prognostic effects of cancer

\begin{tabular}{|c|c|c|c|c|c|c|c|}
\hline & \multirow[t]{2}{*}{ Variable } & \multirow[t]{2}{*}{ Study NO. } & \multirow[t]{2}{*}{ Sample size } & \multirow[t]{2}{*}{ HR(95\%CI) } & \multirow[t]{2}{*}{$P$ value } & \multicolumn{2}{|c|}{ Heterogeneity } \\
\hline & & & & & & $\mathrm{I}^{2}$ & $\mathrm{P}$ value \\
\hline \multirow[t]{13}{*}{ OS } & Overall & 8 & 3289 & $1.75(1.40,2.20)$ & $<0.00001$ & $0 \%$ & 0.79 \\
\hline & \multicolumn{7}{|c|}{ periodontal bacteria } \\
\hline & $\mathrm{Pg}$ & 2 & 346 & $4.04(1.54,10.63)$ & 0.005 & $0 \%$ & 0.64 \\
\hline & Fn & 6 & 2943 & $1.67(1.32,2.11)$ & $<0.0001$ & $0 \%$ & 0.99 \\
\hline & \multicolumn{7}{|l|}{ Ethnicity } \\
\hline & Asia & 6 & 1269 & $1.90(1.43,2.53)$ & $<0.0001$ & $0 \%$ & 0.70 \\
\hline & Caucasian & 2 & 2020 & $1.53(1.05,2.23)$ & 0.03 & $0 \%$ & 0.77 \\
\hline & \multicolumn{7}{|c|}{ Tumor location } \\
\hline & EC & 3 & 671 & $2.13(1.36,3.35)$ & 0.0010 & $15 \%$ & 0.31 \\
\hline & CRC & 5 & 2618 & $1.64(1.26,2.13)$ & 0.0002 & $0 \%$ & 0.97 \\
\hline & \multicolumn{7}{|c|}{ Sample size } \\
\hline & Large & 2 & 2020 & $1.53(1.05,2.23)$ & 0.03 & $0 \%$ & 0.77 \\
\hline & Small & 6 & 1269 & $1.90(1.43,2.53)$ & $<0.0001$ & $0 \%$ & 0.70 \\
\hline \multirow[t]{10}{*}{ DFS } & Overall & 5 & 1384 & $2.18(1.24,3.84)$ & 0.007 & $81 \%$ & 0.0003 \\
\hline & \multicolumn{7}{|c|}{ periodontal bacteria } \\
\hline & Fn & 5 & 1384 & $2.18(1.24,3.84)$ & 0.007 & $81 \%$ & 0.0003 \\
\hline & \multicolumn{7}{|l|}{ Ethnicity } \\
\hline & Asia & 5 & 1384 & $2.18(1.24,3.84)$ & 0.007 & $81 \%$ & 0.0003 \\
\hline & \multicolumn{7}{|c|}{ Tumor location } \\
\hline & $\mathrm{CRC}$ & 5 & 1384 & $2.18(1.24,3.84)$ & 0.007 & $81 \%$ & 0.0003 \\
\hline & \multicolumn{7}{|c|}{ Sample size } \\
\hline & Large & 2 & 873 & $1.46(0.77,2.76)$ & 0.25 & $81 \%$ & 0.02 \\
\hline & Small & 3 & 511 & $3.64(2.53,5.62)$ & $<0.00001$ & $22 \%$ & 0.28 \\
\hline CSS & Overall & 3 & 1674 & $1.85(1.44,2.39)$ & $<0.00001$ & $0 \%$ & 0.51 \\
\hline
\end{tabular}

\section{Figures}




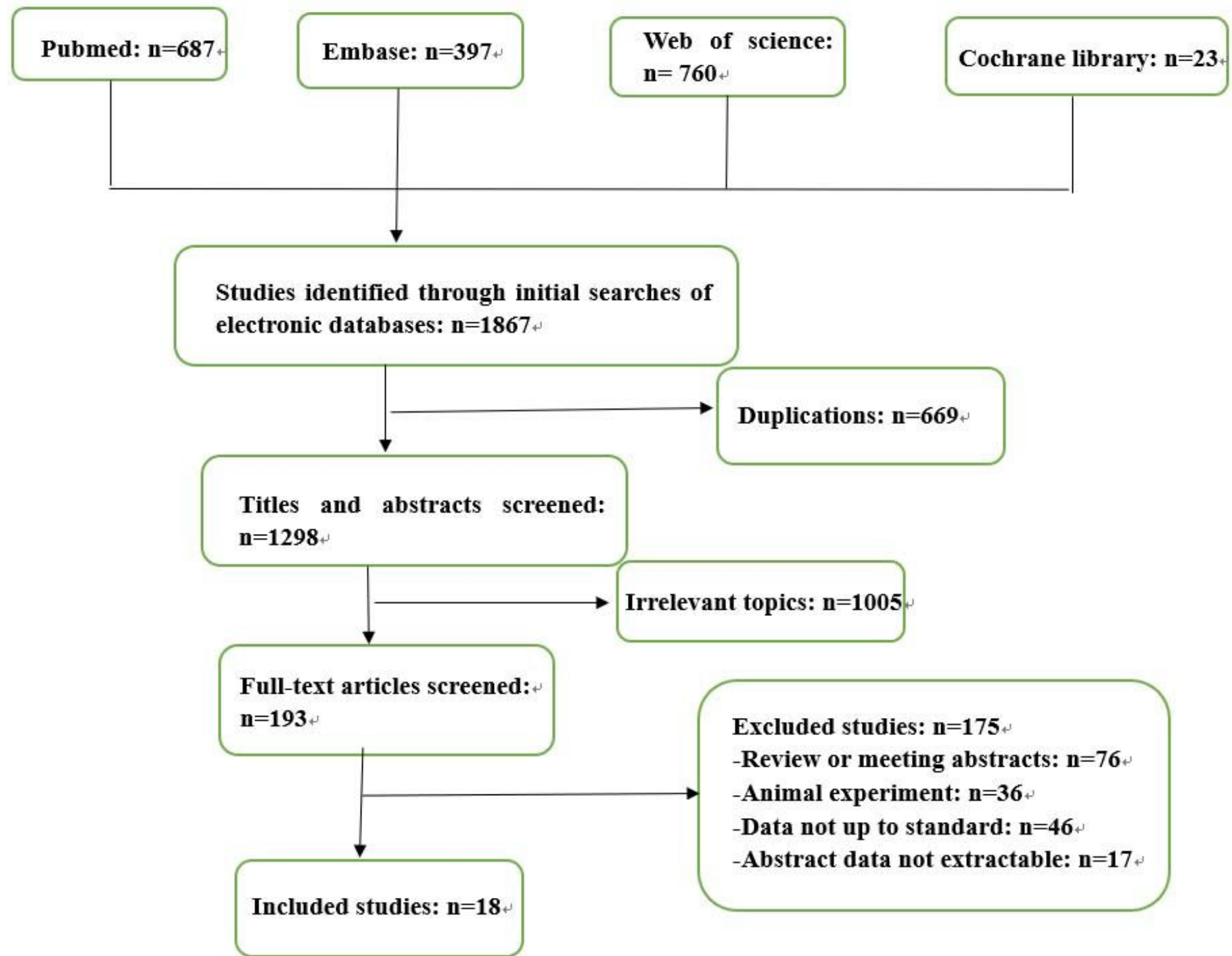

Figure 1

Flow chart of literature search and screening process. 
Experimental Control Odds Ratio Odds Ratio

\begin{tabular}{|c|c|c|c|c|c|c|c|c|}
\hline \multirow{2}{*}{$\begin{array}{l}\text { Studv or Subgroup } \\
1.1 .1 \mathrm{Pg}\end{array}$} & Eveto & Total & \multicolumn{2}{|c|}{ - } & Weight & M-H. Random, $95 \% \mathrm{Cl}$ & \multicolumn{2}{|c|}{ M-H. Random. $95 \% \mathrm{Cl}$} \\
\hline & Events & & & & & \multirow{2}{*}{$10.02[3.11,32.33]$} & \multicolumn{2}{|c|}{$\mid$\begin{tabular}{l|l} 
& \\
\end{tabular}} \\
\hline Chang 2018 & 37 & 61 & 4 & 30 & $2.0 \%$ & & & \\
\hline Fan 2018 & 128 & 361 & 96 & 371 & $6.4 \%$ & $1.57[1.15,2.16]$ & & - \\
\hline Gao 2016 & 71 & 100 & 1 & 29 & $0.8 \%$ & $68.55[8.91,527.67]$ & & $\longrightarrow$ \\
\hline Michaud 2013 & 99 & 405 & 91 & 416 & $6.4 \%$ & $1.16[0.84,1.60]$ & & $\leftarrow$ \\
\hline Peters 2017 & 27 & 106 & 50 & 210 & $4.9 \%$ & $1.09[0.64,1.88]$ & & - \\
\hline Sun 2017 & 25 & 35 & 45 & 70 & $3.0 \%$ & $1.39[0.58,3.35]$ & & 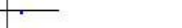 \\
\hline Yang 2018 & 155 & 231 & 260 & 461 & $6.3 \%$ & $1.58[1.13,2.19]$ & & $\rightarrow$ \\
\hline Yuan 2017 & 24 & 50 & 1 & 30 & $0.8 \%$ & $26.77[3.38,211.98]$ & & \\
\hline Subtotal $(95 \% \mathrm{Cl})$ & & 1349 & & 1617 & $30.7 \%$ & $2.16[1.34,3.47]$ & & \\
\hline \multirow{2}{*}{\multicolumn{9}{|c|}{ Heterogeneity: Tau $^{2}=0.29 ; \mathrm{Chi}^{2}=36.42, \mathrm{df}=7(\mathrm{P}<0.00001) ; \mathrm{I}^{2}=81 \%$}} \\
\hline & & & & & & & & \\
\hline \multicolumn{9}{|c|}{ Test for overall effect: $Z=3.18(P=0.001)$} \\
\hline \multicolumn{9}{|l|}{ 1.1.2 If } \\
\hline Fan 2018 & 170 & 361 & 161 & 371 & $6.6 \%$ & $1.16[0.87,1.55]$ & & - \\
\hline Michaud 2013 & 9 & 405 & 9 & 461 & $2.8 \%$ & $1.14[0.45,2.90]$ & & \\
\hline Peters 2017 & 59 & 106 & 105 & 210 & $5.4 \%$ & $1.26[0.79,2.01]$ & & - \\
\hline Sun 2017 & 25 & 35 & 63 & 70 & $2.3 \%$ & $0.28[0.10,0.81]$ & & \\
\hline Yang 2018 & 150 & 231 & 289 & 461 & $6.3 \%$ & $1.10[0.79,1.53]$ & & - \\
\hline Subtotal $(95 \% \mathrm{Cl})$ & & 1138 & & 1573 & $23.4 \%$ & $1.06[0.80,1.41]$ & & \\
\hline Total events & 413 & & 627 & & & & & \\
\hline \multirow{2}{*}{\multicolumn{9}{|c|}{ Heterogeneity: $\mathrm{Tau}^{2}=0.04 ; \mathrm{Chi}^{2}=6.78, \mathrm{df}=4(\mathrm{P}=0.15) ; \mathrm{I}^{2}=41 \%$}} \\
\hline \multicolumn{8}{|c|}{ Test for owerall effect: $Z=0.43(P=0.67)$} & \\
\hline \multicolumn{9}{|l|}{ 1.1.3 Aa } \\
\hline Fan 2018 & 31 & 361 & 15 & 371 & 4. $3 \%$ & $2.23[1.18,4.20]$ & & $\longrightarrow$ \\
\hline Michaud 2013 & 161 & 405 & 190 & 416 & $6.7 \%$ & $0.78[0.59,1.04]$ & & \\
\hline Sun 2017 & 12 & 35 & 34 & 70 & $3.2 \%$ & $0.55[0.24,1.28]$ & & \\
\hline Subtotal $(95 \% \mathrm{Cl})$ & & 801 & & 857 & 14. $1 \%$ & $1.00[0.48,2.08]$ & & \\
\hline Total events & 204 & & 239 & & & & & \\
\hline \multicolumn{9}{|c|}{ Heterogeneity: $\mathrm{Tau}^{2}=0.33 ; \mathrm{Chi}^{2}=10.08, \mathrm{df}=2(\mathrm{P}=0.006) ; \mathrm{I}^{2}=80 \%$} \\
\hline Test for overall effect: & $z=0.00(F$ & $=1.00)$ & & & & & & \\
\hline $1.1 .4 \mathrm{Td}$ & & & & & & & & \\
\hline Peters 2017 & 32 & 106 & 60 & 210 & $5.1 \%$ & $1.08[0.65,1.80]$ & & - \\
\hline Sun 2017 & 23 & 35 & 48 & 70 & $3.1 \%$ & $0.88[0.37,2.08]$ & & - \\
\hline Yang 2018 & 153 & 231 & 260 & 461 & $6.4 \%$ & $1.52[1.09,2.11]$ & & $\therefore$ \\
\hline Subtotal $(95 \% \mathrm{Cl})$ & & 372 & & 741 & $14.5 \%$ & $1.30[0.99,1.72]$ & & $\rightarrow$ \\
\hline Total events & 208 & & 368 & & & & & \\
\hline Heterogeneity: $\operatorname{Tau}^{2}=$ & $0.00 ; \mathrm{Chi}^{2}$ & $=2.13, \mathrm{df}$ & $=2(\mathrm{P}=$ & $=0.35) ; 1$ & $\left.\right|^{2}=6 \%$ & & & \\
\hline Test for overall effect: & $z=1.87(F$ & $=0.06)$ & & & & & & \\
\hline $1.1 .5 \mathrm{Fn}$ & & & & & & & & \\
\hline Yamaoka 2017 & 46 & 72 & 75 & 100 & $4.1 \%$ & $0.59[0.30,1.14]$ & & \\
\hline Yang 2018 & 230 & 231 & 459 & 461 & $0.6 \%$ & $1.00[0.09,11.11]$ & & \\
\hline Subtotal $(95 \% \mathrm{Cl})$ & & 303 & & 561 & $4.7 \%$ & $0.61[0.32,1.16]$ & & \\
\hline Total events & 276 & & 534 & & & & & \\
\hline Heterogeneity: Tau $^{2}=$ & $00 ; \mathrm{Chi}^{2}=$ & $=0.17, \mathrm{df}$ & $=1(P=$ & $0.68) ; 1$ & $\left.\right|^{2}=0 \%$ & & & \\
\hline Test for overall effect: & $=1.51 \mathrm{P}$ & $=0.13)$ & & & & & & \\
\hline 1.1.6 Pi & & & & & & & & \\
\hline Fan 2018 & 82 & 361 & 70 & 371 & $6.1 \%$ & $1.26[0.88,1.81]$ & & $\leftarrow$ \\
\hline Yang 2018 & 149 & 231 & 269 & 461 & $6.4 \%$ & $1.30[0.94,1.80]$ & & $\therefore$ \\
\hline Subtotal $(95 \% \mathrm{Cl})$ & & 592 & & 832 & $125 \%$ & $1.28[1.01,1.63]$ & & 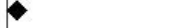 \\
\hline Total events & 231 & & 339 & & & & & \\
\hline Heterogeneity: Tau $^{2}=$ & $00 ; \mathrm{Chi}^{2}=$ & $=0.01, \mathrm{df}$ & $=1(P=$ & $0.92) ; 1$ & $\left.\right|^{2}=0 \%$ & & & \\
\hline Test for overall effect: & $=2.01(\mathrm{P}$ & $=0.04)$ & & & & & & \\
\hline Total $(95 \% \mathrm{Cl})$ & & 4555 & & 6181 & $100.0 \%$ & $1.25[1.03,1.52]$ & & $\bullet$ \\
\hline Total events & 1898 & & 2655 & & & & & \\
\hline Heterogeneity: Tau $^{2}=$ & 13; $\mathrm{Chi}^{2}$ & $=73.48,0$ & $f=22(P$ & $0<0.00$ & $001) ; 1^{2}=$ & $70 \%$ & $12 \quad 0.1$ & \\
\hline Test for overall effect: & $=2.27(\mathrm{P}$ & $=0.02)$ & & & & Favo & is [experimental] & Favours [control] \\
\hline
\end{tabular}

\section{Figure 2}

Forest plot of the association between periodontal bacteria infection and incidence of cancer. 
a

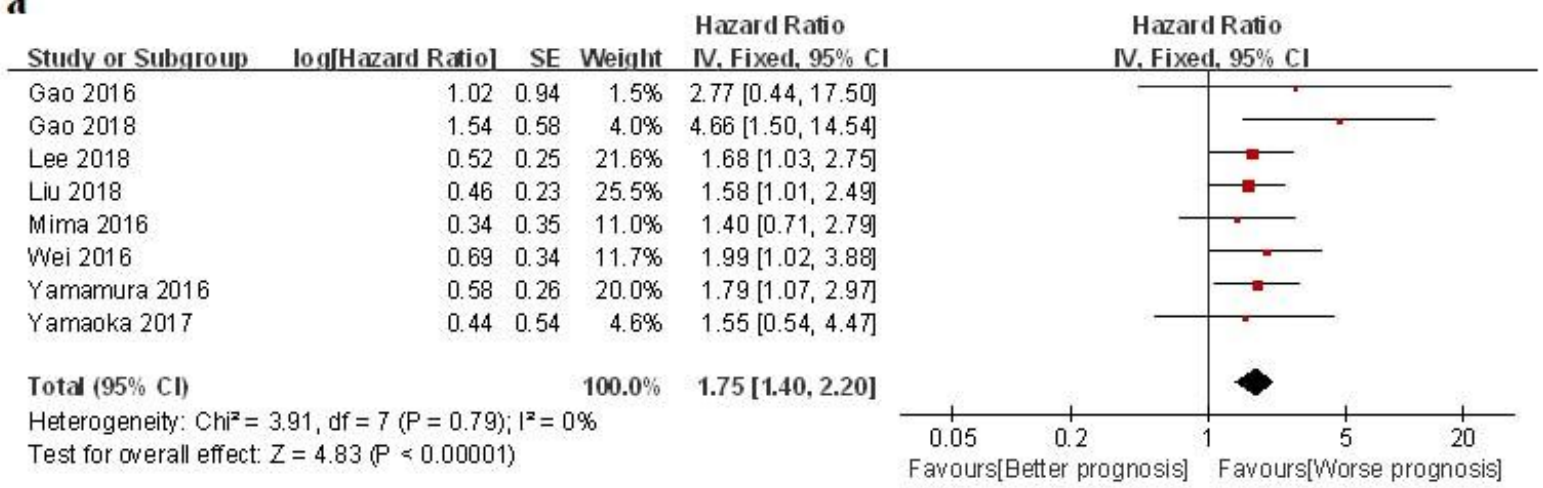

b

\begin{tabular}{|c|c|c|c|c|c|c|c|}
\hline Studv or Subgroup & log[Hazard Ratio] & SE & Weight & $\begin{array}{l}\text { Hazard Ratio } \\
\text { IV. Random. } 95 \% \mathrm{Cl}\end{array}$ & $\begin{array}{r}\text { Hazar } \\
\text { IV. Rando }\end{array}$ & $\begin{array}{l}\text { dRatio } \\
\text { om. } 95 \% \mathrm{Cl}\end{array}$ & \\
\hline Lee 2018 & 0.06 & 0.81 & $8.7 \%$ & $1.06[0.22,5.19]$ & & & \\
\hline Oh 2018 & 0.04 & 0.22 & $23.7 \%$ & $1.04[0.68,1.60]$ & & & \\
\hline Yan 2017 & 0.69 & 0.18 & $24.8 \%$ & $1.99[1.40,2.84]$ & & $\rightarrow$ & \\
\hline$Y \cup 2017$ (cohort1) & 1.46 & 0.35 & $19.5 \%$ & $4.31[2.17,8.55]$ & & $\longrightarrow$ & \\
\hline$Y \cup 2017$ (cohort2)) & 1.32 & 0.23 & $23.4 \%$ & $3.74[2.39,5.88]$ & & $\rightarrow$ & \\
\hline Total $(95 \% \mathrm{CI})$ & & & $100.0 \%$ & $2.18[1.24,3.84]$ & & & \\
\hline \multicolumn{6}{|c|}{$\begin{array}{ll}\text { Heterogeneity: } \text { Tau }^{2}=0.30 ; \mathrm{Chi}^{2}=21.50, \mathrm{df}=4(\mathrm{P}=0.0003) ; \mathrm{I}^{2}=81 \% & +1 \\
\text { Test for overall effect: } Z=2.70(\mathrm{P}=0.007) & \text { Favours[Better prognosis] }\end{array}$} & $\begin{array}{rr}1 & 10 \\
& \end{array}$ & $\begin{array}{r}200 \\
0 \text { isis] }\end{array}$ \\
\hline
\end{tabular}

c

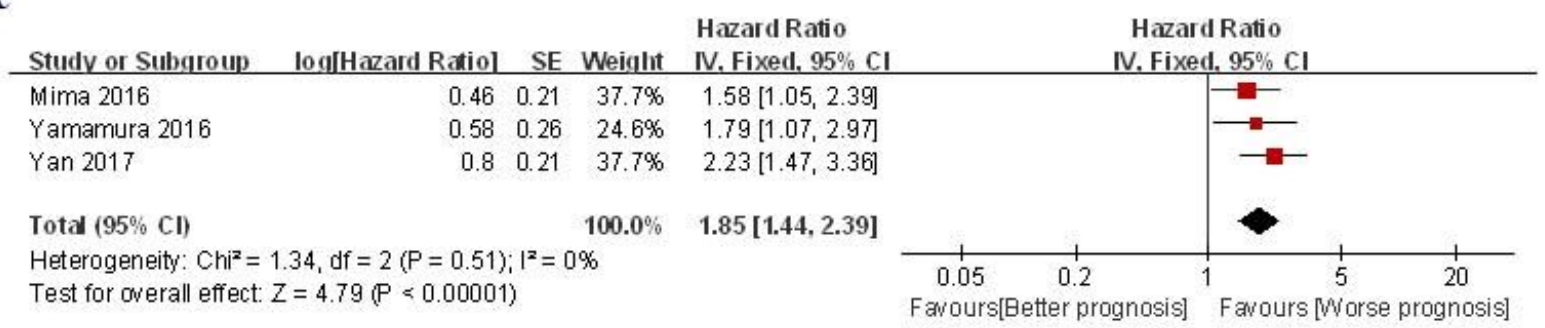

\section{Figure 3}

a Forest plot of the association between periodontal bacteria infection and OS in patients with cancer. b Forest plot of the association between periodontal bacteria infection and DFS and in patients with cancer. c Forest plot of the association between periodontal bacteria infection and CSS in patients with cancer. 
a

Begg's funnel plot with pseudo $95 \%$ confidence limits

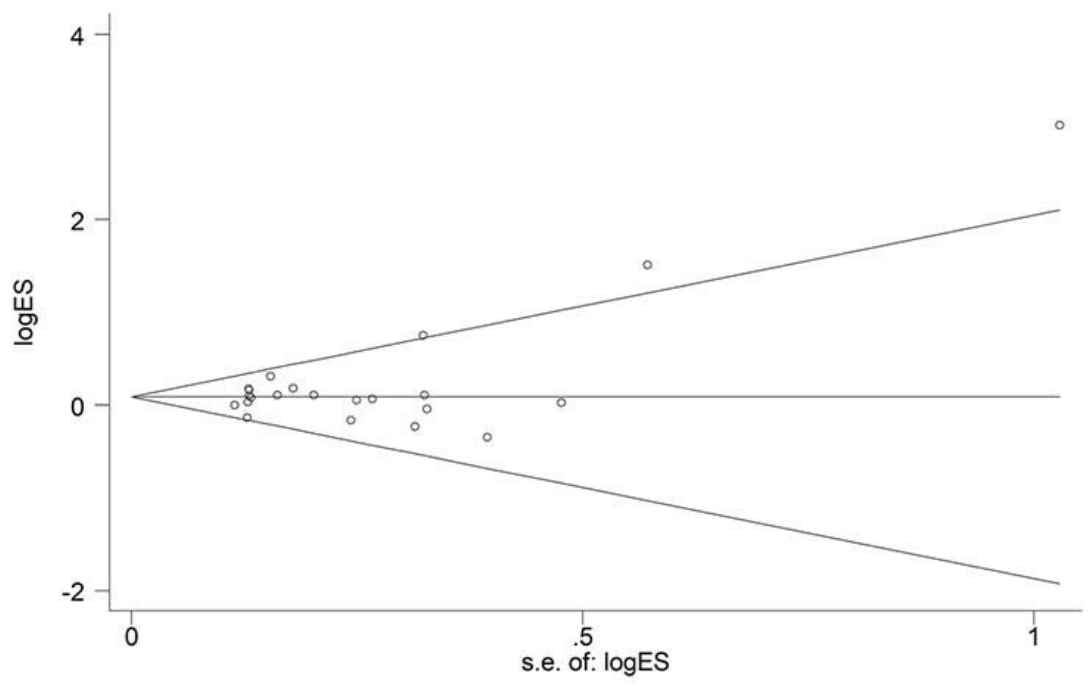

b

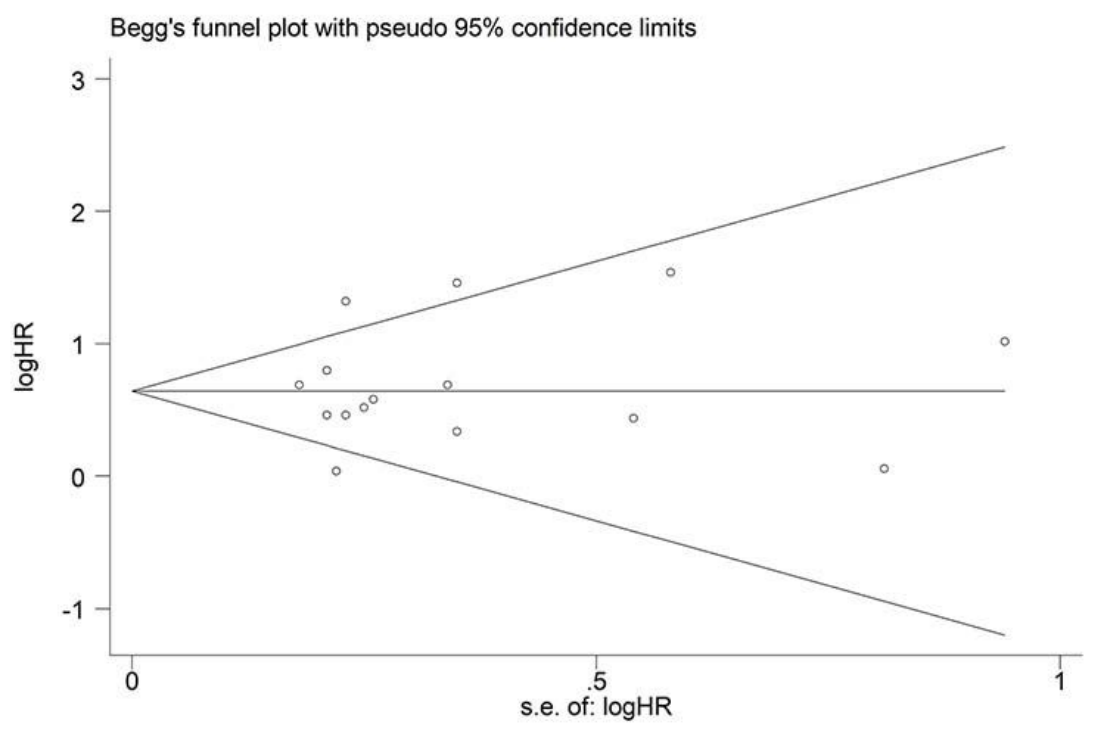

Figure 4

a Begg's funnel plot of publication bias test for incidence in cancer. b Begg's funnel plot of publication bias test for OS, DFS and CSS in cancer.

\section{Supplementary Files}

This is a list of supplementary files associated with this preprint. Click to download.

- SupplementaryFigure3.tif

- SupplementaryFigure5.tif

- SupplementaryTable1.docx

- SupplementaryTable2.docx

- SupplementaryFigure2.tif

- SupplementaryFigure4.tif

- SupplementaryFigure1.tif 